\title{
NOTIUNI DE CERCETARE APLICABILE ÎN CERCETAREA DE ARHITECTURĂ
}

asist. dr. arh. Anda-Ioana Sfinteş *; soc. mrd. antropologie Ruxandra Păduraru **; asist. dr. arh. Ioana E. Zacharias Vultur*

* Universitatea de Arhitectură și Urbanism „Ion Mincu”, București

** Facultatea de Sociologie și Asistență Sociala, Universitatea București

*anda.sfintes@uauim.ro, ruxandra.paduraru@s.unibuc.ro, ioana.vultur@uauim.ro

\section{Introducere}

Identitatea unui spațiu se poate traduce prin totalitatea elementelor umane și nonumane regăsite, prin rețeaua vastă de relații inter- și intraspațiale, prin simboluri și practici spațiale, prin acțiunea unor factori atât interni, cât și externi. Aceste elemente înscrise creează diferite narațiuni ale spațiului, pe care arhitectul/viitorul arhitect are obligația a le cunoaște și descifra.

Cercetarea reprezintă o cale de a lărgi universul "cunoașterii comune" și, totodată, o modalitate de a produce informații contextuale, bazate pe fapte. Teoria existentă în domeniu este recomandat a fi dublată de o cercetare critică bazată pe metode și tehnici bine stăpânite.

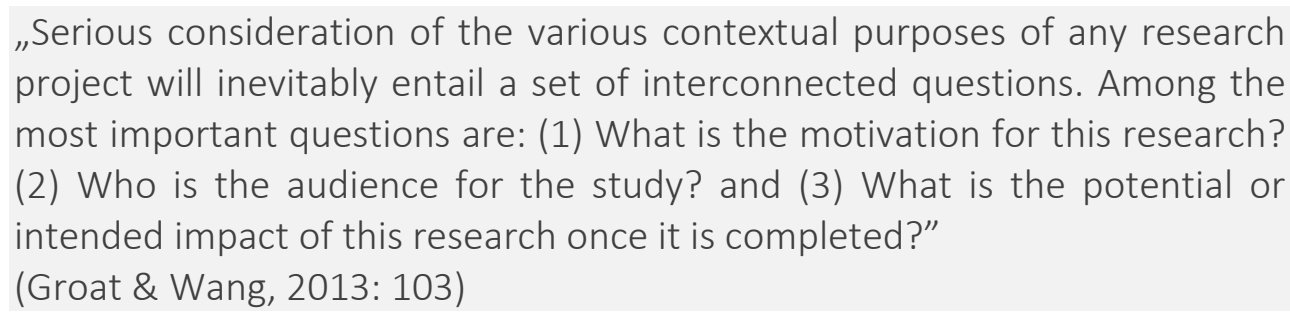

O cercetare desfășurată în parametri buni este adaptată scopului, resurselor de timp și financiare, precum și obiectivelor pe termen scurt, mediu și lung. Aceasta poate viza o analiză a anumitor aspecte, fenomene, a evoluţiei fenomenelor în timp, o analiză a relaţiilor dintre fenomene simultane etc. sau combinaţii ale celor de mai sus. De asemenea, se poate miza pe o cercetare cantitativă sau calitativă, metodele şi tehnicile ce pot fi utilizate fiind variate. Fiecare metodă și combinație de metode are avantaje și dezavantaje; rămâne la latitudinea celui care efectuează cercetarea să stabilească varianta potrivită.

"Often, the built form is evaluated based on its aesthetics and its functionality-attributes that are easy to see and understand. The true value of the built form, however, is the knowledge that informs the design response. That knowledge is less obvious than aesthetics and functionality but is likely more instrumental in creating an outcome that is aligned with the desired goals for the project."

(Augustin \& Coleman, 2012: xxvii) 


\section{Cercetarea cantitativă versus cercetarea calitativă}

Cercetarea cantitativă stabilește legi generale și regularități empirice. Presupune multe cazuri analizate, cercetătorul fiind detașat de acestea. Are avantajul de a fi o măsură obiectivă, prin care se pot testa ipoteze și care permite generalizarea dincolo de eșantionul realizat. Analizele statistice presupun o serie de reguli foarte stricte pentru a asigura veridicitate. Însă, cercetarea cantitativă tratează superficial anumite aspecte, răspunde mai degrabă la întrebările Cum? Cine? În ce fel? decât De ce?, acordă mai puțină atenție sensurilor sociale, neluând în calcul individul în particularitatea sa.

Cuvinte cheie: valori numerice, teste statistice, generalizare

Metode: chestionarul, sondajul, recensământul, statistici teritoriale, analiză de date

Cercetarea calitativă are drept scop descoperirea semnificațiilor, descoperirea punctului de vedere al individului, ține cont de complexitatea acțiunilor umane, critică gândirea liniară. Răspunde la întrebarea De ce?. Cercetarea calitativă presupune analize tematice ale unui număr relativ mic de cazuri și o centrare pe procese interactive. Cercetătorul este implicat, primând autenticitatea. Dezavantajele principale țin de constrângerile situaționale care pot interfera pe parcursul cercetării și de resursa mare de timp alocată.

Cuvinte cheie: context particular, sensuri subiective, interacțiune directă

Metode: observația, interviul, studii de caz, povestea vieții, materiale foto/video, focus grupuri, biografia, studii fenomenologice

\section{Metode de cercetare}

Nu există o singură „cale corectă” de a utiliza tehnicile și instrumentele de cercetare, precum nu există nicio rețetă prestabilită. Cercetătorul poate utiliza de la statistici oficiale până la istorii orale în funcție de contextul studiat. Cercetarea bibliografică este aproape nelipsită din orice tip de cercetare. Observaţia şi întocmirea de hărţi, planuri sunt instrumente de bază în cercetarea de arhitectură. Metodele ce presupun interacţiuni directe (precum interviul şi chestionarul dar şi anumite tipuri de hărţi) pot fi aplicate unor categorii diferite de respondenţi - de la utilizatori ai unui spaţiu până la experţi în anumite domenii. Metode diferite sau combinate de cercetare pot fi aplicate în funcţie de scop.

În continuare vom prezenta pe scurt câteva din metodele de cercetare utilizate în arhitectură, cu recomandarea ca acestea să fie, la rândul lor, studiate în detaliu prin accesarea de resurse dedicate. Volume precum The Designer's Guide to Doing Research: Applying Knowledge to Inform Design (Augustin \& Coleman, 2012) explică pe larg utilitatea aplicării anumitor metode în profesii precum arhitectura, moduri de aplicare corectă, limitări şi recomandări.

Cercetarea bibliografică. Cercetarea bibliografică academică, aplicabilă în context universitar, dar nu limitată la acesta, se bazează pe documentarea resurselor deja existente pe tema dată, precum cărţi şi articole ştiinţifice din domeniul arhitecturii, istoriei, sociologiei, antropologiei, urbanismului, geografiei umane etc., dar și din domenii conexe programului abordat, cercetări care vizează contextul analizat sau actorii identificaţi, arhive de fotografii și filme, documente, articole de ziar, forumuri ale comunității, analiză de date sociologice, studii de caz contextuale, memorii, monografii, jurnale. Aportul unei bune cercetări este găsirea acelor informații care să deschidă orizontul de cunoaștere în funcție de obiectivul propus. Sursele trebuie ierarhizate în funcție de gradul de relevanță și nivelul de încredere în veridicitatea sursei. De asemenea, noutatea sursei nu constituie un imperativ, însă este de așteptat ca o lucrare bună să conțină 
și surse de actualitate. Disocierea între surse academice (articole de specialitate, cărți, etc.) și surse populare (grupuri de Facebook, site-uri, forumuri, blog-uri) constituie un element cheie. Cercetarea bibliografică este adesea de tip bulgăre de zăpadă - referințele utilizate de un autor într-o lucrare care conține informații utile pot fi consultate pentru o înțelegere mai în profunzime.

Cercetarea bibliografică trebuie să urmărească o gamă largă de surse care să acopere nevoia de informaţii. De exemplu, într-o cercetare istorică documentele ce pot fi investigate sunt:

_ planuri istorice succesive ale așezării din care face parte imobilul pentru a identifica evoluția relației cu așezarea, a parcelarului, a etapelor de construcție, relația cu vecinătățile și elemente de identitate a locului. Concret, prin analiza stratigrafică se poate înțelege o anumită evoluție, se pot data cu mai multă precizie anumite informații care apar pe un plan de urbanism: elemente de toponimie, topografie, dimensiuni de parcelă, vegetație, categorie de construcții, numerotare, funcțiune, formă în plan, vegetație, etc., dar și caracterul locului în diferite etape istorice.

_ documente de arhivă: planuri de aliniament, autorizații de construire, scrisori, informații despre proprietate, piesele desenate originale ale imobilului, publicații ale vremii în care acesta este menționat - monografii, ziare, anuare, cărți de telefon, fotografii, etc.

_ bibliografii recente primare și secundare care tratează așezarea, imobilul sau programul de arhitectură, direct sau indirect: monografii, albume, articole de cercetare, etc.

_ webografii (dacă există) pe aceleași criterii. Dacă situl sau imobilul este de mare importanță se recomandă și consultarea marilor arhive online, autohtone sau internaționale (de ex. planuri și documente istorice unice despre București pot fi consultate gratuit pe site-ul Biblitheque Nationale de France).

_ colecţii (reale sau digitale) ale oricăror piese care conțin informații relevante: cărți poștale, afișe, fotografii de epocă, etc.

Aceste piese documentare trebuie raportate la temă, la complexitatea proiectului și timpul ce poate fi acordat cercetării. Pe baza lor se poate formula o ipoteză de intervenție și argumenta o anumită poziție a proiectului.

Observația participativă presupune participarea activă (într-o măsură mai mare sau mai mică) a cercetătorului la activităţile cercetate sau care se desfăşoară în terenul cercetat, imersare în cadrul studiat, parcurgerea aceloraşi experiențe, purtarea de discuții informale. Implicarea cercetătorului poate spori încrederea comunității în acesta, poate contribui la identificarea unor aspecte altfel neaccesibile şi astfel la o mai bună înţelegere a comunităţii sau fenomenelor cercetate. Este important ca cercetătorul să se conformeze rigorilor și normelor comunității pe care o studiază, dar păstrându-și totuși distanța necesară observării (conform cu scopul stabilit şi postura pe care şi-o asumă - de individ din interiorul sau din exteriorul comunităţii cercetate).

Observația neparticipativă implică doar privitul sau ascultatul (fără a lua parte implicit la activitate) şi imparţialitatea (nu trebuie formate opinii, formulate judecăţi de valoare).

"Observe without forming opinions - be a sponge."

(Augustin \& Coleman, 2012: 203) 
Observaţia poate fi exploratorie (încercând să identifice posibile criterii care să stea la baza analizei ulterioare), sau poate urmări criterii clare, prestabilite, caz în care se pune accent pe raportarea corectă a criteriilor la momentele în care se desfăşoară cercetarea (de exemplu, urmărirea activităţii dintr-o piaţă doar la o anumită oră nu oferă o imagine completă a utilizării care poate să difere în funcţie de oră, zi, condiţii climatice, anotimp etc.).

Întocmirea de hărţi şi planuri [mapping] este o metodă adesea regăsită în cercetările de arhitectură. Aceasta poate consta, de exemplu, în:

_ întocmirea de hărţi cognitive/mentale - reprezentare grafică, făcută de către respondenţi, in baza unei cerinţe clar formulate de către cercetător;

- întocmirea de hărţi comportamentale - în care sunt ilustrate comportamente ale utilizatorilor în strânsă legătură cu spaţiul cercetat;

_ planuri adnotate (planuri pe care sunt făcute notaţii, observaţii diverse, conform temei urmărite).

Această metodă este deosebit de diversă și poate consta în alcătuirea de schițe, planuri sau chiar noi hărţi, în folosirea unor aplicații de "tracking" sau a unor platforme specializate, folosirea unor hărți deja existente pe care subiecții își pot reprezenta singuri trasee, repere etc. sau pe care cercetătorul poate interveni marcând aspectele urmărite etc.

Tipuri de reprezentări precum cele menţionate mai sus pot contribui la înţelegerea unor aspecte precum: cum se mișcă oamenii prin oraș sau printr-un spaţiu, unde se opresc, care le sunt reperele principale, care sunt rutele principale, cum percep spațialitatea și distanțele, care sunt zonele cele mai frecventate, toate acestea ducând la identificarea spațiilor optime de intervenție în concordanță cu fluxurile existente.

Chestionarul este un mijloc de culegere a datelor la scară mare, util în special în determinări (eventual procentuale) ale poziţiei respondenţilor în raport cu problema ridicată, în determinări ale gradului de apreciere a anumitor elemente, fenomene pe baza unor criterii etc. Întrebările formulate trebuie să fie clare, precise, scrise într-un limbaj propriu respondenţilor. În conceperea unui chestionar accentul cade pe alcătuirea corectă a întrebărilor şi succesiunea lor logică. Răspunsurile obţinute în urma chestionarelor pot fi comparate, corelate, împărţite pe categorii, se pot urmări relaţii între variabilele stabilite etc.

Interviul. Deşi se bazează tot pe obţinerea de răspunsuri la întrebări (dar de data aceasta nu neapărat predefinite), interviul are avantajul posibilităţii adaptării întrebărilor la răspunsurile subiectului, al observării comportamentelor nonverbale şi al obţinerii de răspunsuri spontane. Astfel se poate explora mai în profunzime subiectul cercetat, cu condiţia formulării corecte a întrebărilor, în acest caz cel mai mare risc fiind constituit de obţinerea de răspunsuri nesincere ca urmare a unei formulări care indică un tip de răspuns aşteptat/dorit.

Interviul se poate desfăşura într-un mod mai mult sau mai puţin formal. Un tip informal de interviuri pot fi considerate discuţiile purtate însoţind respondentul de-a lungul unui traseu [walk and talk].

Studiul de caz. Selectarea studiilor de caz trebuie făcută după criterii clare astfel încât rezultatele să fie relevante în cadrul cercetării. Printre cele mai importante criterii se numără: similaritatea cu programul sau funcţiunile studiate, scara obiectului de arhitectură, corespondenţa contextuală etc. 
"the case study involves studying a case in relation to the complex dynamics with which it intersects and from which the case itself is inseparable."

(Groat \& Wang, 2013: 421)

Studiile de caz pot contribui la înţelegerea în profunzime a modului în care un obiect de arhitectură (prin caracteristicile sale) şi/sau programul asociat funcţionează în relaţie cu alte elemente şi/sau context, la identificarea unor rezolvări specifice urmărind impactul lor, la identificarea percepţiilor la care conduc, a modului în care au fost apropriate etc.

\section{Referințe}

Augustin, S., \& Coleman, C. (2012). The Designer's Guide to Doing Research: Applying Knowledge to Inform Design. John Wiley \& Sons, Inc.

Babbie, E. (2010). Practica cercetării sociale. Iași: Polirom

Chelcea, S. (2004). Inițiere în cercetarea sociologică, București: comunicare.ro

Chelcea, S. (2007). Metodologia cercetării sociologice. București: Editura Economică

Groat, L. N., \& Wang, D. (2013). Architectural Research Methods. Wiley. 